\title{
Effects of bone cement loaded with teicoplanin, N-acetylcysteine or their combination on Staphylococcus aureus biofilm formation: an in vitro study
}

\author{
Teikoplanin, $\mathrm{N}$-asetil sistein veya bunların kombinasyonunu içeren kemik çimentosunun \\ Stafilokokkus aureus biyofilm oluşumuna etkileri: in vitro bir çalışma
}

\author{
Hasan Göçer, MD., ${ }^{1}$ Dilek Emir, MD., ${ }^{2}$ Mehmet Emin Önger, MD., ${ }^{3}$ Nevzat Dabak, MD. ${ }^{1}$ \\ 'Department of Orthopedics and Traumatology, Medical Faculty of Ondokuz Mayıs University, Samsun, Turkey \\ 2Department of Medical Microbiology, Medical Faculty of Ondokuz Mayıs University, Samsun, Turkey \\ ${ }^{3}$ Department of Histology and Embryology, Medical Faculty of Ondokuz Mayıs University, Samsun, Turkey
}

\begin{abstract}
Objectives: This study aims to demonstrate the antibiofilm effects of teicoplanin alone, $\mathrm{N}$-acetyl cysteine (NAC) alone, or combination of both compounds when mixed with bone cement.
\end{abstract}

Materials and methods: A total of four groups were formed by using six cement samples in each, prepared with bone cement having different contents in each group. Group 1 (control group): cement alone without any drugs added. Group 2: $40 \mathrm{~g}$ cement, $400 \mathrm{mg}$ teicoplanin. Group 3: 40 g cement, 6 g NAC. Group 4: 40 g cement, 6 g NAC, $400 \mathrm{mg}$ teicoplanin. All cement samples were infected with Staphylococcus aureus for 48 hours at $36.5{ }^{\circ} \mathrm{C}$. Bacterial colonies were then counted by serial dilution method. Bacteria were counted using scanning electron microscopic (SEM) images.

Results: Counts of bacteria colonies were $5.83 \pm 1.60$ [mean colony forming unit (cfu) x $10^{5} \pm$ standard deviation (SD)] in group $1,0.12 \pm 0.56$ in group $2,0.11 \pm 0.65$ in group 3, and $0.01 \pm 0.001$ in group 4 . Significant difference was found between group 1 and all other groups ( $\mathrm{p}<0.05)$, and between group 4 and all other groups $(\mathrm{p}<0.05)$. According to SEM analysis, counts of bacteria $($ mean $\pm \mathrm{SD})$ were $1.88 \pm 0.45,0.75 \pm 0.26,0.21 \pm 0.22$, and $0.13 \pm 0.25$ in groups $1,2,3$, and 4 , respectively. Significant difference was found between group 1 and all other groups $(\mathrm{p}<0.05)$, and between group 4 and all other groups $(\mathrm{p}<0.05)$.

Conclusion: N-acetyl cysteine, teicoplanin, and their combination significantly reduced formation of biofilm compared to the control group. Also, combination of NAC and teicoplanin had the highest antibiofilm effect.

Keywords: Biofilm; bone cement; $\mathrm{N}$-acetylcysteine; periprosthetic joint infection; Staphylococcus aureus; teicoplanin.

\section{$\ddot{z z}$}

Amaç: $\mathrm{Bu}$ çalışmada sadece teikoplaninin, sadece $\mathrm{N}$ asetil sistein (NAC)'in veya her iki bileşenin kombinasyonunun kemik çimentosuyla karıştırılmasının antibiyofilm etkileri gösterildi.

Gereç ve yöntemler: Her grupta farklı içeriğe sahip kemik çimentosu ile hazırlanan altışarlı çimento kalıplar kullanılarak toplam dört grup oluşturuldu. Grup 1 (kontrol grup): Herhangi bir ilaç katılmaksızın sadece çimento. Grup 2: $40 \mathrm{~g}$ çimento, $400 \mathrm{mg}$ teikoplanin. Grup 3: $40 \mathrm{~g}$ çimento, $6 \mathrm{~g}$ NAC. Grup 4: $40 \mathrm{~g}$ çimento $6 \mathrm{~g}$ NAC, $400 \mathrm{mg}$ teikoplanin. Tüm çimento kalıpları Stafilokokkus aureus ile 48 saat $36.5^{\circ} \mathrm{C}$ 'de enfekte edildi. Bakteri kolonileri seri dilüsyon yöntemiyle sayıldı. Bakteriler taramalı elektron mikroskobik (TEM) görüntüler kullanılarak sayıldı.

Bulgular: Bakteri kolonisi sayıları grup 1'de 5.83 \pm 1.60 [ortalama koloni oluşturan birim (kob) x $10^{5} \pm$ standart sapma (SS)], grup 2'de $0.12 \pm 0.56$, grup 3'te $0.11 \pm 0.65$ ve grup 4'te $0.01 \pm 0.001$ idi. Grup 1 ile tüm diğer gruplar arasında $(\mathrm{p}<0.05)$ ve grup 4 ile tüm diğer gruplar arasında anlamlı farklılık bulundu ( $\mathrm{p}<0.05)$. TEM analize göre, bakteri sayıları (ort. $\pm \mathrm{SS}$ ) grup $1,2,3$ ve 4 'te sirasiyla $1.88 \pm 0.45,0.75 \pm 0.26,0.21 \pm 0.22$ ve $0.13 \pm 0.25$ idi. Grup 1 ile tüm gruplar arasında $(\mathrm{p}<0.05)$ ve grup 4 ile tüm gruplar arasında anlamlı farklılık bulundu $(\mathrm{p}<0.05)$.

Sonuç: $\mathrm{N}$ asetil sistein, teikoplanin ve bunların kombinasyonu kontrol grubuna göre biyofilm oluşumunu anlamlı olarak azalttı. Ayrıca, NAC ve teikoplanin kombinasyonu en yüksek antibiyofilm etkisine sahipti.

Anahtar sözcükler: Biyofilm; kemik çimentosu; N asetil sistein; periprostetik eklem enfeksiyonu; Stafilokokkus aureus; teikoplanin.

- Received: June 29, 2016 Accepted: December 07, 2016

- Correspondence: Hasan Göçer, MD. Ondokuz Mayıs Üniversitesi Tıp Fakültesi Ortopedi ve Travmatoloji Anabilim Dalı, 55105 Atakum, Samsun, Turkey. Tel: +90 362 - 3121919 / 2361 e-mail: drhasangocer@hotmail.com 
As the number of major joint arthroplasty (hip-knee arthroplasty) procedures has been increasing, the number of periprosthetic joint infections (PJIs) has also been increasing. Infections around the implant are among the most problematic issues of prosthetic medical care, and the treatment of a PJI that has a biofilm on the implant surface is almost impossible without removing the implant ${ }^{[1]}$ In particular, biofilm produced by staphylococci are extremely difficult to eradicate.

Biofilms are composed of polysaccharides, an extracellular polymeric matrix, extracellular DNA, and proteins, all of which protect the bacteria from antibiotics and the host's defenses. Therefore, in a medical setting, the complete removal of the patient's implant, combined with the application of antibioticloaded cement (ALC) is recommended to treat PJIs and eradicate the biofilm. Via the application of an ALC, either the local antibiotic concentration is increased, or the adverse effects of a systemic antibiotic are prevented. ${ }^{[2]}$ ALCs prepared with appropriate antibiotics can be used if the bacteria responsible for the infection can be identified in the culture. However, since bacteria may not always be identified before or during surgery, an ALC prepared with broadspectrum antibiotics is usually applied, although this PJI treatment may not always be successful.

Although N-acetylcysteine (NAC) is generally used solely as a mucolytic agent, ${ }^{[3]}$ it also has antibacterial properties. ${ }^{[4]}$ For example, NAC decreases the bacterial production of extracellular polysaccharides; these extracellular polysaccharides normally facilitate the formation of bacterial biofilms on implants, and NAC disrupts these biofilms. ${ }^{[5]}$
The scanning electron microscopy (SEM) is useful equipment for descriptive morphology and bacterial counting. It is also adaptable, and its results are very reproducible ${ }^{[6]}$ For these reasons, we used the SEM to quantitatively investigate the morphological changes in the intensity of the biofilms.

In this study, we aimed to demonstrate the antibiofilm effects of teicoplanin alone, NAC alone, and combination of both compounds when mixed with bone cement.

\section{MATERIALS AND METHODS}

This study was conducted between 03.02.2016 and 15.04.2016 in a laboratory designed for microbiology and the study of infectious diseases. Four groups -each containing six samples- of bone cement were used (Figure 1). All of the preparations were performed under sterile conditions at approximately $70 \%$ humidity. Group 1 (control group) samples were prepared with $40 \mathrm{~g}$ of bone cement (Implantcast, $\mathrm{GmbH}$, Buxtehude, Germany) without additional drugs. For groups 2-4, samples were prepared by mixing the bone cement for one minute to create a homogenous liquid, then adding the drug solution to the cement. Group 2 samples consisted of $40 \mathrm{~g}$ of bone cement and $400 \mathrm{mg}$ of teicoplanin ( $400 \mathrm{mg}$ lyophilized Targocid; Sanofi Aventis, Italy). Group 3 samples consisted of $40 \mathrm{~g}$ of bone cement and $6 \mathrm{~g}$ of NAC (Merck Millipore, Germany). Group 4 samples consisted of $40 \mathrm{~g}$ of bone cement, $6 \mathrm{~g}$ of NAC, and $400 \mathrm{mg}$ of teicoplanin.

The strong biofilm-producing strain of Staphylococcus aureus (S. aureus) 'ATCC 25923' (American Type Culture Collection USA) was selected
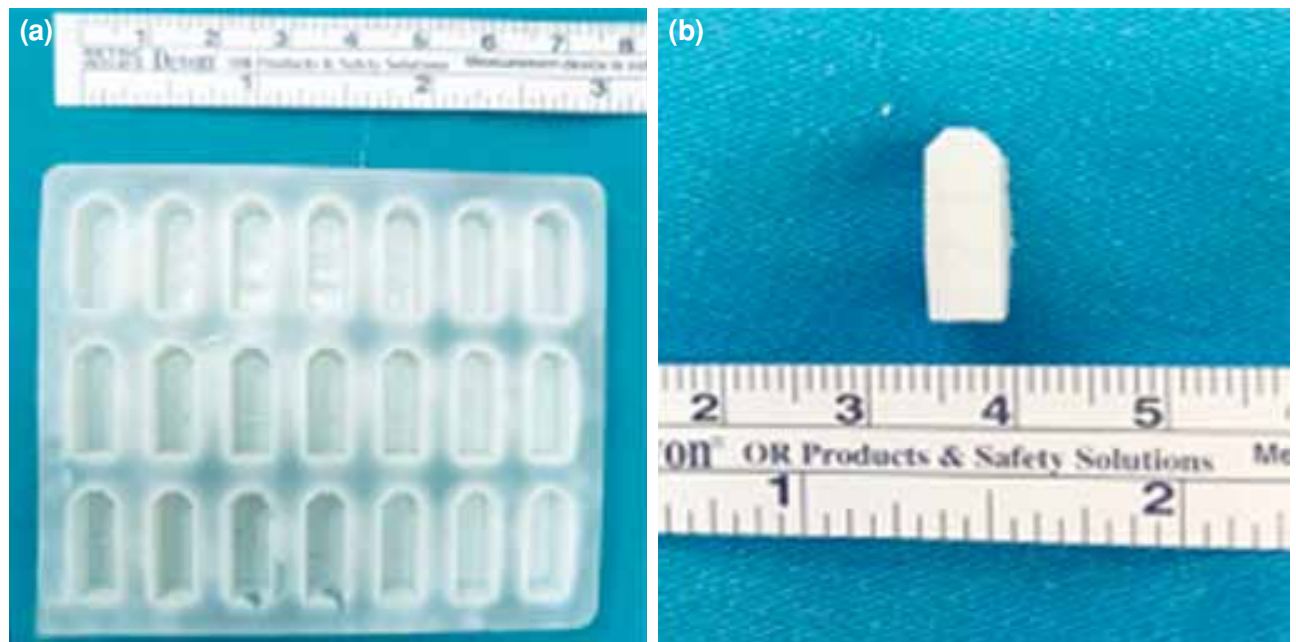

Figure 1. Preparation of samples. (a) Silicon embedding chamber was used to obtain uniform sample sizes. (b) Standardized sample. 
for use in this study. ${ }^{[7]} \mathrm{A}$ suspension of these bacteria with turbidity equivalent to a $0.5 \mathrm{McF}$ arland standard $\left(\sim 10^{8}\right.$ colony forming unit $\left./ \mathrm{mL}\right)$ was prepared in Trypticase Soy Broth (TSB; BBL, Cockeys- ville, MD, USA) supplemented with $0.5 \%$ glucose. All bone cement samples were inoculated with this solution and incubated for 48 hours at $36.5^{\circ} \mathrm{C} \cdot{ }^{[8]}$ After the incubation, samples were put into sterile saline ( $0.9 \%$ sodium chloride) for one minute to remove the planktonic cells.

\section{Culture analysis}

Samples were moved to sterile, lidded vessels containing $10 \mathrm{~mL}$ of a sterile saline solution, and were then vortexed for three minutes. The biofilm layer of the bacterial colonies was thus removed from the surface of each sample and converted into a bacterial suspension. To quantify the colonies, serial dilutions $(1 / 10,1 / 100$, $1 / 500)$ were prepared for each sample using the bacterial suspension and additional volumes of sterile saline. From these solutions, samples were cultured onto agarbased medium plates containing $5 \%$ sheep's blood, and were then incubated for 48 hours at $36.5{ }^{\circ} \mathrm{C}$. Bacterial colonies were then counted (Figure 2). ${ }^{[9]}$

\section{Scanning electron microscopy analysis}

Six samples from each group were used to quantify bacterial growth via SEM. Morphological changes in the biofilms on the samples were evaluated using SEM images obtained with a
JSM-7001F STEM (JEOL Ltd., Tokyo, Japan). The samples were dried to the critical point and coated with gold-palladium, and then examined in eight selected areas under 10,000x magnification (Figure 3). The histological scoring system was used for scoring the level of biofilm formation, ${ }^{[10]}$ and the quantity of bacteria [S. aureus] present was scored as $0-25=1,26-50=2$ and $>50=3$ (Figure 3).

\section{Statistical analysis}

All of the statistical analyses were performed using the SPSS statistical software package, version 14.0 (SPSS Inc., Chicago, IL, USA). Data are presented as the mean \pm standard deviation. A normality test (KolmogorovSmirnov) was performed, followed by one-way analysis of variance, and a Kruskal-Wallis H-test. $\mathrm{P}<0.05$ was considered to be statistically significant.

\section{RESULTS}

\section{Culture analysis}

The effects of NAC, teicoplanin, or the combination of both compounds on biofilm formation by S. aureus were evaluated. Data are shown in Table I. Groups 2 and 3 showed significant reductions in sample colonization by bacteria when compared to the control samples in group $1 \quad(p<0.05)$. Group 3 showed amounts of biofilm formation that were equivalent to those observed in group 2 $(p>0.05)$. Overall, group 4 showed the lowest amounts

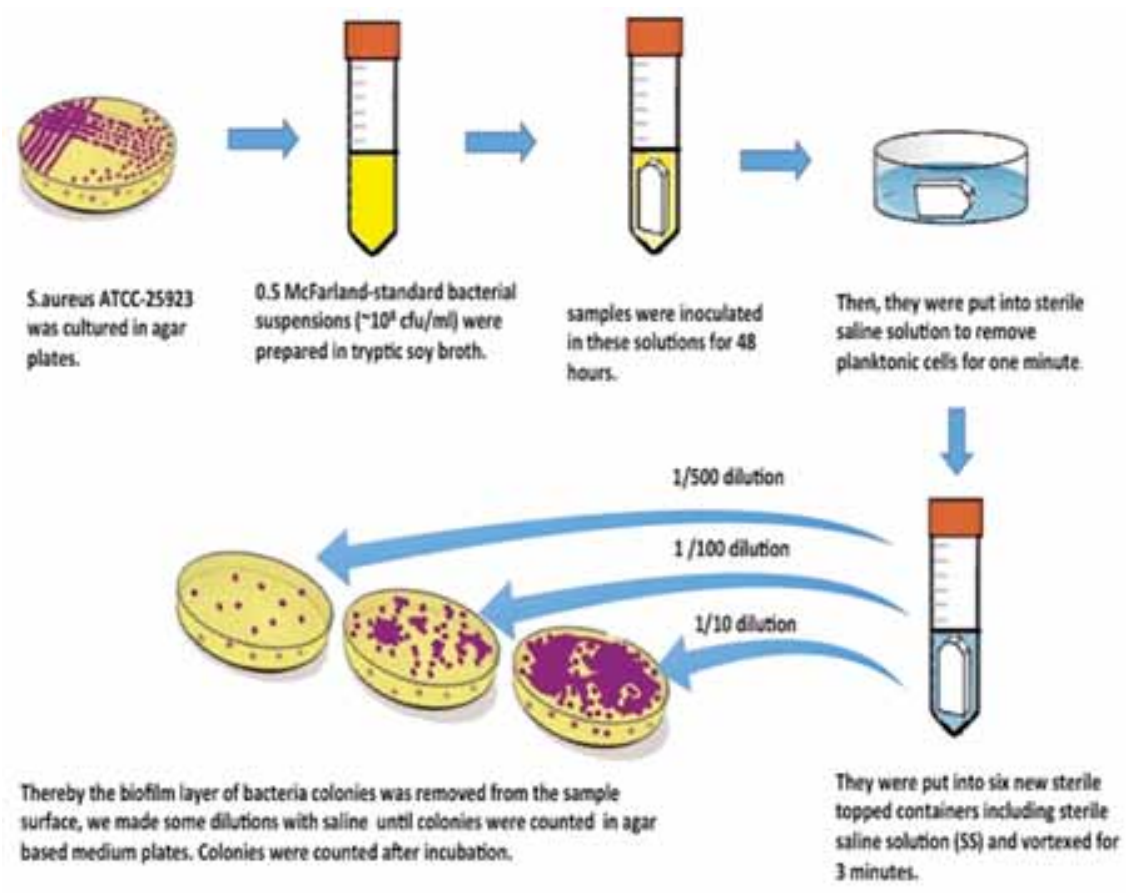

Figure 2. Schematic illustration of colonial counting steps by dilution method. 

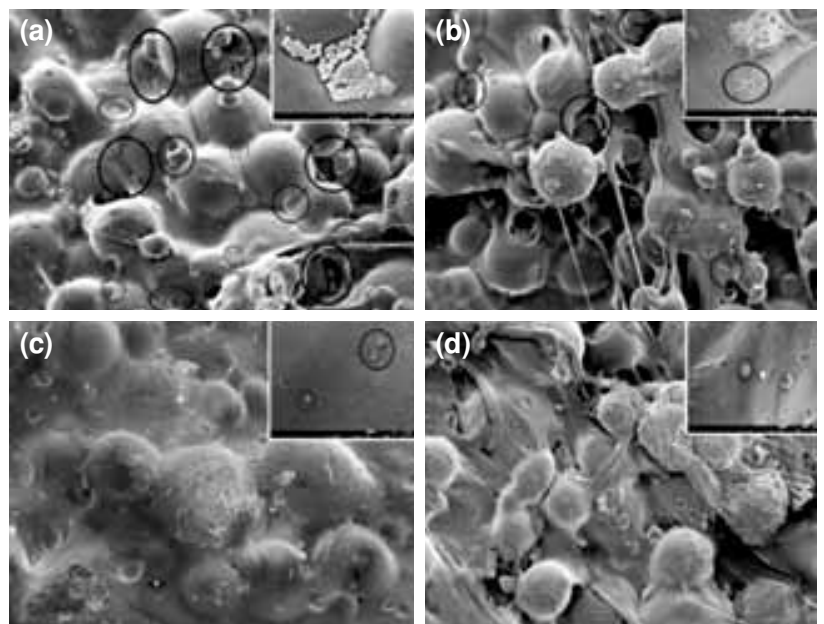

Figure 3. Scanning electron micrographs showed the effects of teicoplanin alone (b), $\mathrm{N}$-acetylcysteine alone (c) and both in combination (d) respectively on a performed $S$. aureus biofilm developed in vitro on samples surfaces. A dense mass of biofilm (cocci bacteria) can be seen in group 1 (a). Decreases in the amount of biofilm mass adhering to the bone cement surfaces can be observed for experimental groups 2, 2, and 4 (b, c, and d). B shows the effect that teicoplanin has on the ability of $S$. aureus to form biofilm. Cells appeared scattered with no biofilm mass observed on the surface. Irregularly shaped cells and small microcolonies were also observed. $\mathrm{C}$ shows the morphological response of $S$. aureus when grown in the presence of $\mathrm{N}$-acetylcysteine. Cells appeared disrupted and scattered with no biofilm mass. D shows the effect of teicoplanin $+\mathrm{N}$-acetylcysteine combination on a performed $S$. aureus biofilm. Cells appeared disrupted and scattered. A significant decrease in the number of adherent cells was observed. (Magnification: 450; Scale Bar: $10 \mu \mathrm{m}$ ).

of sample colonization by bacteria when compared to all other groups $(\mathrm{p}<0.05)$.

\section{Scanning electron microscopy analysis}

Upon examination, samples that were positive for bacterial growth showed biofilm formation (Table II). When the bacterial colony counts were evaluated, significant differences were found between groups 1 and 2, 1 and 3, 1 and 4 and 2 and $4(\mathrm{p}<0.05)$; however, there was no statistical difference between groups 2 and 3 ( $p>0.05)$.

\section{DISCUSSION}

The most important finding of this study was that samples loaded with NAC showed significant reductions in biofilm production by $S$. aureus when compared to the control samples. This organism was selected because it is the most common infecting agent in PJI.

Periprosthetic joint infections continue to receive a high level of attention because of the increasing number of major joint arthroplasty procedures being performed. Moreover, the most significant cause of arthroplasty failure is a PJI. PJIs are caused by surface-adhering microorganisms, which, with regard to the surgical area, adhere to the implants and form biofilms. ${ }^{[1]}$ Biofilm formation occurs in five stages. In the first stage, biofilm deposition occurs on the surface of the material via bacterial adhesion, creating the first biogenic substrate, in what is referred to as an initial or 'reversible attachment' phase. The bacteria then produce, and become encased in, a polymeric matrix that anchors them to the substrate in the second stage, which is referred to as an irreversible attachment' phase. During the third stage, in the presence of sufficient environmental stimulation, the bacteria undergo a shift in genetic expression. In the fourth stage, the biofilm grows and becomes a threedimensional structure, providing mass transfer. In the fifth and final stage, the bacteria within the biofilm are dispersed into the surrounding environment. ${ }^{[12]}$ Because of this, implants associated with major joint arthroplasty are considered a predisposing factor for patients to develop PJIs. ${ }^{[13]}$ The biofilm protects the bacteria from host defense mechanisms and local or systemic antibiotics by slowing their diffusion. Thus, PJIs are resistant to both systemic and local treatment.

There have been many studies of implant compounds, shapes, and coverings that could prevent biofilm formation; prevention is critically important, because a biofilm is difficult to treat after it has started to grow. ${ }^{[14]}$ For example, cobalt-chromium is more suitable than titanium in terms of preventing bacterial adhesion. Silver can prevent the formation of a biofilm either by gram-positive or gram-negative bacteria; therefore, silver-coated implants can decrease the probability of a PJI. ${ }^{[15]}$ Copper, zinc, and iron also have antibiofilm properties; however, their usage in implants is limited because, with prolonged exposure which translates to high effective dosages to the patient, they have toxic effects on soft tissues, thus their usage is limited. An antibiotic-coated implant can also have antimicrobial effects, and antibiotic-loaded bone cement is a preferred material for primary arthroplasty by some authors. ${ }^{[16]}$

Orthopedic surgeons have different approaches for the management of PJIs and other complications of total knee arthroplasty and total hip arthroplasty. ${ }^{[17]}$ Onestage or two-stage revision surgery can be performed. A one-stage revision procedure is advised for patients who have severe comorbidities. However, because the biofilm grows not only on the periprosthetic surfaces, but also on the periprosthetic soft tissue, most authors prefer a two-stage revision procedure. The two-stage 
TABLE I

Colony counts, by groups on agar culture

\begin{tabular}{lc}
\hline & Mean \pm SEM \\
\hline Group 1 & $5.8 \pm 1.6$ \\
Group 2 & $0.1 \pm 0.6$ \\
Group 3 & $0.1 \pm 0.7$ \\
Group 4 & $0.01 \pm 0.001$
\end{tabular}

SEM: Scanning electron microscopy; Colony counts (mean colony forming unit $\mathrm{x} 10^{5} \pm \mathrm{SEM}$ ) (S. aureus).

\section{TABLE ॥}

Bacteria counts using scanning electron microscopy

\begin{tabular}{lc}
\hline & Bacteria (S. aureus) \\
\cline { 2 - 2 } & Mean \pm SD \\
\hline Group 1 & $1.9 \pm 0.5$ \\
Group 2 & $0.3 \pm 0.1$ \\
Group 3 & $0.2 \pm 0.1$ \\
Group 4 & $0.01 \pm 0.001$ \\
\hline
\end{tabular}

SD: Standard deviation.

revision has some advantages; namely, the pathogen is cleared, and a rational antibiotic is used. In the two-stage revision surgeries, after all implants' hardware has been removed, a spacer -prepared with an ALC-is used. ${ }^{[17]}$ The spacer preserves the otherwise empty space left behind by the removal of the implant hardware, and achieves a high local concentration of antibiotics in the area while minimizing systemic side effects. Additionally, a PJI can be treated by covering it with ALC, which precludes the removal of a well-fixed implant. ${ }^{[18]}$

Prior to a revision surgery, if the preoperative cultures are negative, broad-spectrum antibiotics are preferred. PJI treatments may require a long period of time to succeed, or may even be unsuccessful, and recurrent surgeries may be required. ${ }^{[19]}$ In those cases, different approaches can be beneficial in treating unidentified bacteria. Due to its mucolytic effects, NAC can be used for different medical indications. ${ }^{[3]}$ Moreover, there have been studies showing that NAC has bactericidal effects on several different microorganisms, including $S$. aureus, Staphylococcus epidermidis, Pseudomonas aeruginosa (P. aeroginosa), Klebsiella pneumoniae and Candida albicans. ${ }^{[2,21]}$ Therefore, NAC may be used in broadspectrum antimicrobial and antibiofilm therapeutics. We hypothesized that samples loaded with NAC might prevent the formation of biofilms, and might also be effective in treating PJIs. NAC affects several processes that are important for bacterial biofilm formation on stainless steel surfaces, including drastically reducing extracellular polysaccharide production, and thus acts as an antibiofilm substance. ${ }^{[22]}$ Leite et al. ${ }^{[5]}$ have also reported that NAC alone $(40 \mathrm{mg} / \mathrm{L})$, or in combination with rifampicin $(10 \mathrm{mg} / \mathrm{L})$, reduces the formation of S. epidermidis biofilms. Only one study performed by Onger et al. ${ }^{[23]}$ and using in vitro techniques has demonstrated the synergistic effect achieved when bone cement is loaded with both NAC and ciprofloxacin. This is the second study to show the effects of NAC-loaded samples on biofilm formation. However, in the aforementioned study carried out by Onger et al., ${ }^{[23]}$ the antibiofilm effects of NAC were shown on gram-negative bacteria ( $P$. aeroginosa), which are rarely associated with PJIs. By contrast, for the current study, we chose to use gram-positive bacteria (S. aureus); these are the most common infecting agents in PJIs. Furthermore, $S$. aureus strains produce stronger biofilm than $P$. aeroginosa. ${ }^{[1]}$ We found that the NAC and teicoplanin show similar effects on $S$. aureus, with a significant decrease in the number of colonies formed $(\mathrm{p}<0.05)$. However, the combination of NAC with teicoplanin was more effective than NAC alone or teicoplanin alone. Consistent with the findings of previous studies, we determined that NAC and teicoplanin show the synergistic efficiency against biofilms caused by $S$. aureus. To the best of our knowledge, bone cement loaded with NAC and teicoplanin has not been studied previously.

Using SEM images, we also quantitatively examined the preventative effects of NAC and teicoplanin on $S$. aureus biofilm formation. We determined that while the bacterial count was highest in the negative control samples (bone cement alone), they were significantly reduced in the bone cement samples loaded with NAC; and the NAC-loaded samples showed bacterial load reductions similar to those of the teicoplanin-loaded samples. However, SEM analyses showed the bacterial numbers to be the lowest in samples where NAC and teicoplanin had both been added. Therefore, we have demonstrated that NAC-loaded bone cement prevents the formation of biofilms, and can be used in the treatment of PJIs.

Although bone cement does have cytotoxic effects on some tissues, the NAC reduces the cytotoxicity of the cement. ${ }^{[24]}$ Remarkably, Aita et al. ${ }^{[25]}$ showed that the NAC-loaded bone cement prevents osteoblastic cytotoxicity. Because NAC appears to not cytotoxic, it has been used in concentrations as high as $6 \mathrm{~g}$. There is a practical upper limit to the amount of NAC that can be added to bone cement, ${ }^{[26]}$ but the aim of this study was not to examine the mechanical stability of NAC-loaded bone cement. We believe that NAC can be combined with sensitive drugs to treat patients 
when their test cultures are positive for S. aureus; and this combination treatment may also prevent bacterial growth on the patient's implant or soft tissues even if the cultures from the PJI are negative for $S$. aureus. Future studies using different microorganisms, such as gram-negative bacteria, anaerobic bacteria or fungi should be carried out, as they can lead to new levels of understanding regarding how PJIs form. In addition, before NAC-loaded spacers can be used in the treatment of PJIs, in vivo studies are needed in humans.

The limitations of our study include the following: 1) NAC was tested at only single dosage; 2) dilution tests for NAC were not performed;3) mechanical test of the treated bone cement samples were not performed; and 4) cytotoxicity tests were not performed.

In conclusion, the combination of NAC and teicoplanin showed the greatest reduction of biofilm formation on bone cement samples, but NAC treatment reduced biofilm formation on such samples just as effectively as teicoplanin treatment.

\section{Declaration of conflicting interests}

The authors declared no conflicts of interest with respect to the authorship and/or publication of this article.

\section{Funding}

The authors received no financial support for the research and/or authorship of this article.

\section{REFERENCES}

1. McConoughey SJ, Howlin R, Granger JF, Manring MM, Calhoun JH, Shirtliff $\mathrm{M}$, et al. Biofilms in periprosthetic orthopedic infections. Future Microbiol 2014;9:987-1007.

2. Ocguder A, Firat A, Tecimel O, Solak S, Bozkurt M. Two-stage total infected knee arthroplasty treatment with articulating cement spacer. Arch Orthop Trauma Surg 2010;130:719-25.

3. Hu HC, Liu HC, Chen YH, Huang CC, Wan GH, Chou LT, et al. The impact of aerosolized mucolytic agents on the airflow resistance of bacterial filters used in mechanical ventilation. J Formos Med Assoc 2015;114:717-21.

4. Zhao T, Liu Y. N-acetylcysteine inhibit biofilms produced by Pseudomonas aeruginosa. BMC Microbiol 2010;10:140.

5. Leite B, Gomes F, Teixeira P, Souza C, Pizzolitto E, Oliveira R. Staphylococcus epidermidis biofilms control by $\mathrm{N}$-acetylcysteine and rifampicin. Am J Ther 2013;20:322-8.

6. Afrikian EG, St Julian G, Bulla LA Jr. Scanning electron microscopy of bacterial colonies. Appl Microbiol 1973;26:934-7.

7. Coraça-Hubér DC, Fille M, Hausdorfer J, Pfaller K, Nogler M. Evaluation of MBEC ${ }^{\mathrm{TM}}-\mathrm{HTP}$ biofilm model for studies of implant associated infections. J Orthop Res 2012;30:1176-80.

8. Zago CE, Silva S, Sanitá PV, Barbugli PA, Dias CM, Lordello $\mathrm{VB}$, et al. Dynamics of biofilm formation and the interaction between Candida albicans and methicillin-susceptible (MSSA) and -resistant Staphylococcus aureus (MRSA). PLoS One 2015;10:0123206.

9. Ben-David A, Davidson CE. Estimation method for serial dilution experiments. J Microbiol Methods 2014;107:214-21.
10. Abramov Y, Golden B, Sullivan M, Botros SM, Miller JJ, Alshahrour A, et al. Histologic characterization of vaginal vs. abdominal surgical wound healing in a rabbit model. Wound Repair Regen 2007;15:80-6.

11. Zimmerli W, Moser C. Pathogenesis and treatment concepts of orthopaedic biofilm infections. FEMS Immunol Med Microbiol 2012;65:158-68.

12. Padera RF. Infection in ventricular assist devices: the role of biofilm. Cardiovasc Pathol 2006;15:264-70.

13. Brady RA, Leid JG, Calhoun JH, Costerton JW, Shirtliff ME. Osteomyelitis and the role of biofilms in chronic infection. FEMS Immunol Med Microbiol 2008;52:13-22.

14. Arciola CR, Campoccia D, Speziale P, Montanaro L, Costerton JW. Biofilm formation in Staphylococcus implant infections. A review of molecular mechanisms and implications for biofilm-resistant materials. Biomaterials 2012;33:5967-82.

15. Eto S, Kawano S, Someya S, Miyamoto H, Sonohata M, Mawatari M. First Clinical Experience With Thermal-Sprayed Silver Oxide-Containing Hydroxyapatite Coating Implant. J Arthroplasty 2016;31:1498-503.

16. Hinarejos P, Guirro P, Puig-Verdie L, Torres-Claramunt R, Leal-Blanquet J, Sanchez-Soler J, et al. Use of antibioticloaded cement in total knee arthroplasty. World J Orthop 2015;6:877-85.

17. Azboy İ, Yalvaç ES, Azboy N, Şahin İ, Zehir S. Preferences of surgeons in total knee and hip arthroplasty, and operating room facilities in Turkey: a survey. [Article in Turkish] Eklem Hastalik Cerrahisi 2016;27:34-40.

18. Ekpo TE, Berend KR, Morris MJ, Adams JB, Lombardi AV Jr. Partial two-stage exchange for infected total hip arthroplasty: a preliminary report. Clin Orthop Relat Res 2014;472:437-48.

19. Parvizi J, Erkocak OF, Della Valle CJ. Culture-negative periprosthetic joint infection. J Bone Joint Surg Am 2014;96:430-6.

20. Aslam S, Darouiche RO. Role of antibiofilm-antimicrobial agents in controlling device-related infections. Int J Artif Organs 2011;34:752-8.

21. Yamada M, Ishihara K, Ogawa $T$, Sakurai K. The inhibition of infection by wound pathogens on scaffold in tissue-forming process using N-acetyl cysteine. Biomaterials 2011;32:8474-85.

22. Leite B, Gomes F, Teixeira P, Souza C, Pizzolitto E, Oliveira R. Combined effect of linezolid and $\mathrm{N}$-acetylcysteine against Staphylococcus epidermidis biofilms. Enferm Infecc Microbiol Clin 2013;31:655-9.

23. Onger ME, Gocer H, Emir D, Kaplan S. N-acetylcysteine eradicates Pseudomonas aeruginosa biofilms in bone cement. Scanning 2016;38:766-70.

24. Tsukimura N, Yamada M, Aita H, Hori N, Yoshino F, Chang-Il Lee $\mathrm{M}$, et al. $\mathrm{N}$-acetyl cysteine (NAC)-mediated detoxification and functionalization of poly(methyl methacrylate) bone cement. Biomaterials 2009;30:3378-89.

25. Aita H, Tsukimura N, Yamada M, Hori N, Kubo K, Sato N, et al. N-acetyl cysteine prevents polymethyl methacrylate bone cement extract-induced cell death and functional suppression of rat primary osteoblasts. J Biomed Mater Res A 2010;92:285-96.

26. Hsieh $\mathrm{PH}$, Shih $\mathrm{CH}$, Chang $\mathrm{YH}$, Lee MS, Yang WE, Shih HN. Treatment of deep infection of the hip associated with massive bone loss: two-stage revision with an antibiotic-loaded interim cement prosthesis followed by reconstruction with allograft. J Bone Joint Surg [Br] 2005;87:770-5. 